\title{
The Competitive Significance of Segmented Markets
}

\author{
Kenneth M. Davidson $\dagger$
}

The Justice Department's new Merger Guidelines place a greater emphasis on mergers in homogeneous product markets than on mergers in heterogenous markets. ${ }^{1}$ This emphasis is a result of the Department's focus on price fixing as the most important competitive problem to arise from concentrated markets. According to the Guidelines, homogeneity is a condition that facilitates reaching consensus and detecting deviation. ${ }^{2}$.

This Article argues that there may be cause for greater concern in segmented (i.e., non-homogeneous) markets. For example, consider the lawfuhress under the new Guidelines of a merger in a hypothetical beverage product market:

Two inerging beverage firms have market shares of $9 \%$ and $5 \%$. Their merger would increase the Herfindahl-Hirschman Index $(\mathrm{HHI})^{3}$ from 1200 to 1290 points. The product is differentiated by three quality categories (special, premium and regular) and by two quantity categories (bulk sales to taverns and restaurants, and bottle sales to individuals). Despite the similarity of production processes, ouly two of the fourteen firms in the industry have a significant presence in more than one product category. All the beverages are further differentiated by heavy advertising and brand loyalty.

Because the HHI for the industry is under 1800 points, the Guidelines would define this hypothetical product market as moderately concentrated. ${ }^{4}$ Under the Guidelines, absent "Other Factors,"s such a

$\dagger$ Professor of Law, University of Bridgeport School of Law. B.A. 1963, University of Chicago; J.D. 1966, University of Pennsylvania; LL.M. 1967, Yale University. Former Deputy Assistant Director, Bureau of Competition, Federal Trade Commission. The views expressed in this Artiele are personal and are not intendcd to reflect the views of the Federal Trade Commission or any of the Commissioners. I wish to thank Roberta Baruch, Richard Craswell, Thomas Jorde, Robert Lande and John Morgan for their helpful comments on earlier drafts of this Article.

1. U.S. Dep't of Justice, Merger Guidehines $\S \operatorname{III}(C)(1)(a), 47$ Fed. Reg. 28,493, 28,498 (1982), reprinted in 71 CALIF. L. REv. 649, 658 (1983) [hereinafter cited without cross-reference as Guidehines].

2. Id.

3. See id. $\$ \mathrm{II}(\mathrm{A}), 47 \mathrm{Fed}$. Reg. at $28,497,71$ CALIF. L. Rev. at $655-56$ (defines the Herfindahl-Hirschman Index $(\mathrm{HHI})$ as a number "calculated by summing the squares of the individual market shares of all the firms included in the market . . . .").

4. The Guidelines define market concentration as "a function of the number of firms in a market and their respective inarket shares." Id. They specify three levels of market concentration 
merger likely would not be challenged because concentration is increased by less than 100 points. The degree of product homogeneity is an "Other Factor."' Because this product market is differentiated, i.e., not hoinogeneous, the Guidelines assert that explicit collusion is less likely to occur because of the difficulty of establishing and enforcing "a coinplex schedule of prices corresponding to gradations in actual or perceived quality attributes . ..."7 Consequently, it is unlikely that the Department would challenge the inerger.

The Guidelines' einphasis on collusive price agreennents as the source of market power may result in a failure to consider coinpetitive dangers caused by concentration in seginented inarkets. For exainple, in the hypothetical inarket described above, the firms could achieve inarket power ${ }^{8}$ in either of two ways. Firms could agree to allocate each other different seginents of the inarket. Alternately, by reducing the number of coinpetitors, the merger might inake obvious to all firms that it is advantageous to specialize in different seginents of the inarket. In this way, market power could be achieved without any explicit agreeinent between coinpetitors. In either case, if consummation of the merger would increase market power, the inerger should be prevented.

This Article argues that the Guidelines' focus on price collusion is misdirected to the extent they ignore less evident, but potentially more serious, competitive problems associated with seginented markets. Although the Antitrust Division's view that collusion can be facilitated by product hoinogeneity has support, hoinogeneity may also add to a particular product market's coinpetitive vitality by inaking cartel agreements less stable. Moreover, business strategy literature provides soine reason to believe that coinpetitive problems in seginented markets are inore difficult to remedy than those in hoinogeneous product inarkets. ${ }^{9}$ Firms in segmented inarkets have a greater opportunity to enhance their profits over sustained periods. Such firms can pursue independent yet compatible business strategies without explicitly colluding. ${ }^{10}$ Ac-

using the HHI: unconcentrated (below $1000 \mathrm{HHI}$ ), highly concentrated (above $1800 \mathrm{HHI}$ ) and moderately concentrated (between 1000 and $1800 \mathrm{HHI}$ ). Id. $\S \mathrm{III}(\mathrm{A})(1), 47$ Fed. Reg. at 28,497, 71 CAlif. L. Rev. at 656-57.

5. The Guidelines discuss a group of "Other Factors" that "affect the likelillood that a merger will create, enhance or facilitate the exercise of market power." Id. \& III(C), $47 \mathrm{Fcd}$. Reg. at 28,498-99, 71 CALIF. L. REv. at 657-58. These other factors include, inter alia, homogeneity of products and presence of detailed information about specific transactions. Id.

6. Id. $\S \mathrm{III}(\mathrm{C})(1)(\mathrm{a}), 47 \mathrm{Fed}$. Reg. at 28,498, 71 CALIF. L. Rev. at 658.

7. Id.

8. The Guidelines define inarket power as the "ability of one or more firms profitably to maintain prices above competitive levels for a significant period of time." Id. \& I, 47 Fed. Reg. at 28,494, 71 CALIF. L. Rev. at 650.

9. See infra text accompanying notes $45-49$.

10. The implications of this conduct are discussed infra in Part II of this Article. 
cordingly, the Justice Departinent should also include seginentation as an "Other Factor"11 to consider when examining mergers.

Because the identification of market structures that facilitate market power is fundanental to a rational merger policy, I lave sketched the different competitive implications of concentration in both hoinogeneous and seginented product unarkets. This is not a detailed presentation of the differences between homogeneous and seginented product markets; rather, this Article argues that the Guidelines, while generally useful, have ignored the serious potential for competitive problems in seginented markets. I suggest that the potential for interfirm cooperative behavior posed by some segmented product markets is greater for a number of reasons. First, competition in segmented narkets is less direct, and therefore less effective. Second, such markets are more in need of antitrust attention than hoinogeneous product narkets where anticompetitive agreements tend to be unstable. Fimally, there is greater difficulty im detecting anticompetitive conduct by firms in segmented inarkets. Thus, seginented product markets are least amenable to control by conduct rules and most im need of structural attention. Section 7 of the Clayton Act is particularly well suited to addressing this problein, for it forbids mergers whose effect "nnay be substantially to lessen competition or tend to create a monopoly." 12 It is intended as a prophylactic measure to prevent harms to competition that are encouraged by a concentrated market structure and that cither cannot be detected or, if detected, cannot be eliminated by rules establishing permissible coinpetitive conduct. Therefore, the Guidelines should take care to prevent concentration in segmented product markets because such structures facilitate maintenance of excess profits.

Part I of this Article argues that firms in homogeneous product markets may find it difficult to collude simply because of the hoinogeneity of the product. I suggest that the conditions that create the imcentive to collude in homogeneous markets-often overcapacity and industry negative earnings - can also prevent prices from being raised to a competitive, much less to a supracompetitive level, without an exphicit and closely momitored agreement. Part II then argues that cheating is less likely in segmented markets because such markets are more stable, thus making cooperative behavior nore likely. In addition, I suggest that segmented markets should be prime targets for section 7 enforcement because such markets present the potential for collusion in ways that cannot easily be reached by the antitrust laws once the collusion has been established.

11. See supra note 5 .

12. Clayton Act $\S 7,15$ U.S.C. $§ 18$ (Supp. IV 1980). 


\section{Homogeneous Product Markets}

The Guidelines maintain that a homogeneous and undifferentiated product nnarket poses the greatest danger of cartel behavior because the firms in the market need agree on only one variable-priceto cartelize effectively. ${ }^{13}$ Simplicity, the Justice Department seems to say, nnakes the earning of collective monopoly profits more likely. This rehance on conventional wisdom, ${ }^{14}$ while no doubt justified in many cases, ignores the characteristics of homogeneous markets that inhibit or undermine the operation of a cartel. Both price theory and case law suggest that the operation of a cartel is not simple. History suggests that some explicit cartels in homogeneous product markets were formed in futile attempts to protect industries plagued by overcapacity and below normal profits.

\section{A. Theory}

Microeconomic price theory teaches that a cartel is formed to raise price and maximize profit by limiting both firm and industry output. ${ }^{15}$ The primcipal theoretical obstacle to forming a successful cartel (in countries where a cartelization agreement is not legally enforceable) is the incentive for an individual firm to cheat by secretly lowering its price. This increases the cheater's sales and profits to the detriment of other firms in the industry. ${ }^{16}$ Firms that suffer loss of sales and profits due to cheating would be forced to lower their prices. Price theory suggests that the incentive to cheat and the need of other firms to respond makes cartel agreeinents inherently unstable and likely to result in a reduction of price to the competitive level. ${ }^{17}$

Even if it is assumed that no firms will cheat, an alternate theoretical obstacle exists to forming a successful cartel. If the cartel earns monopoly profits, firms outside the market will be induced to enter the market. These entrants will destabilize the cartel by increasimg output and forcing prices down.

Price theory teaches that these cheatimg scenarios are most likely to occur in homogeneous markets. Because the products are liomogeneous, buyers are assumed to be highly price sensitive and likely to switch

13. Guidelines $\S \operatorname{III}(C)(1), 47$ Fed. Reg. at 28,498, 71 CALIF. L. Rev. at 658.

14. See, e.g., R. Posner, ANTItrust LAW 59-60 (1976); G. Stigler, The Theory of Price 219-20 (1966).

15. See, e.g., E. Mansfield, Microeconomics 344-46 (4th ed. 1982).

16. Id. at 357. See also A. AlChIAN \& W. ALLEN, UNIVERSITY ECONOMICs 176-79 (1st ed. 1964) (describing the same cheating propensity in buyers' cartels).

17. There is disagreement in the literature as to how long higher prices will persist before destabilization forces prices down to competitive levels. 
to another seller for even slight price savings. The more differentiated the product inarket, the less likely buyers are to switch to another seller. ${ }^{18}$ The Guidelines, however, are most concerned with hoinogeneous product markets. ${ }^{19}$ In effect, the Guidelines assert that the greatest anticompetitive threat arises from agreements between firms in product inarkets that are most likely to be unstable.

Presumably, the justification for this apparent anomaly is that even if there is an incentive to cheat, the fact that in a hoinogeneous product inarket the firms need agree on only one variable-i.e., pricefacilitates development of a cartel. It is easier to detect cheating if one can look only at price. When a cartel must agree on other factors such as quality, service, or volume, it is inore difficult to police the agreement. I wonld add another reason for concern about cartels in homogeneous products markets: firms are tempted to reduce competition by cartelization, inerger, or monopolization precisely because volatile and unstable conditions are likely to exist where products of different firms are interchangeable. ${ }^{20}$

Theory cannot predict whether in the real world it is simple, and therefore effective, to monitor price agreements. If monitoring is not simple, then cheating should cause the cartel to collapse. The tendency of cartels to be unstable is increased if, as is true under our antitrust laws, the agreeinents nuust either be kept secret or be limited to matters that have only an indirect effect on facilitating price agreements. Accordingly, the Guidelines' concern with homogeneous markets inust be justified by experience.

\section{B. Experience}

While there is ample experience to justify concern with price fixing in hoinogeneous product markets, ${ }^{21}$ that experience also provides some indication that collusion has not been motivated solely by a desire to obtain inonopoly profits. Instead, price instability or less than normal rates of return have also provided the inotivation. Although motivation inay be unimportant in establishing Sherinan Act violations, ${ }^{22}$ it is

18. For a discussion of other ways sellers can discourage buyers from switching to a competitors' products, see, e.g., M. Porter, Competitive Strategy 19, 114, $227-28$ (1980).

19. See supra note 1 and accompanying text.

20. Posner states: "Where the product is a fungible commodity, cutting prices may be the only way of getting business away from a competitor; if so, eliminating price competition is sure to yield higher profits." R. POSNER, supra note 14, at 60 (emphasis added).

21. Scherer's review of the empirical literature indicates that the evidence from antitrust prosecutions is consistent with the conclusion that collusion is more often found in homogeneous product markets. F. Scherer, Industrial Market Structure ANd EConomic Performance 175-76 (1980). Scherer states that "agreement is easier to achieve when the number of sellers is modest-e.g., ten or fewer . . . ." Id.

22. Price fixing is, in general, a per se violation of Sherman Act $\S 1$, 15 U.S.C. $\S 1$ (1976), 
an indicator of inarket characteristics (e.g., a trend of falling prices). These characteristics nay persist even after establishing a cartel, thus contributing to its failure.

One indication of frequent price instability in homogeneous markets is the persistent assertion of antitrust defenses claiming that cartels are needed to stabilize industry earnings. An explicit declaration of the need for cooperative behavior throughout the industry is used repeatedly as a defense in price fixing and facilitating practice (i.e., busimess practices that facilitate price fixing) cases. ${ }^{23}$ For example, in United States v. Trenton Potteries Co. ${ }^{24}$ it was argued that the agreement between the firms slould be lawful because the agreed upon prices were reasonable and necessary to the stability of the industry. The Court unequivocally rejected the argument, reasoning that price fixing can never be justified on the basis of market conditions. In similar cases where the objective of industry cooperation was characterized in similar terms, such as "to keep prices at reasonably stable and norinal levels,"2s the Supreme Court has usually held the conduct unlawful.

Despite numerous defeats, economic necessity defenses contmued to be raised in appeals to the Supreme Court involving hoinogeneous products. ${ }^{26}$ This strategy indicates the felt need of soine industries to lessen "destructive" coinpetition. The cases, however, do not support the view that this cartel-like behavior had either provided supracoinpetitive earnings to the industry as a whole or its leading meinbers, ${ }^{27}$ or discouraged exit from declining industries. Neither do the cases suggest that it is a simple matter to momitor prices and production even when dealing with homogeneous goods. The monitoring or coordination activity was often cumbersome and obvious to enforcennent agencies.

Programs of voluntary price stabilization by firms within an industry have frequently been unsuccessful in homogeneous product mar-

and considered unlawful without regard to intent. See L. Sullivan, HandBook of the Law of ANTITRUST $\$ \S 59,74$ (1977).

23. See, e.g., United States v. Container Corp. of Am., 393 U.S. 333 (1969); United States v. Socony-Vacuuin Oil Co., 310 U.S. 150 (1940); Sugar Inst. v. United States, 297 U.S. 553 (1936); Appalachian Coals, Inc. v. United States, 288 U.S. 344 (1933); United States v. Trenton Potteries Co., 273 U.S. 392, 396-97 (1927); Maple Flooring Mfg. Ass'n v. United States, 268 U.S. 563 (1925); American Column \& Lumber Co. v. United States, 257 U.S. 377 (1921).

24. 273 U.S. 392 (1927).

25. American Column \& Lunber Co. v. United States, 257 U.S. 377,393 (1921).

26. See supra note 23 and cases cited therein. Defendants won only in Maple Flooring and Appalachian Coals.

27. Because price fixing is a per se violation of the antitrust laws, only the agreement or the practice that facilitates price fixing need be proven. The Court, therefore, did not have occasion to determine whether the colluding firms actually obtained monopoly profits. See L. Sullivan, supra note $22, \S 70$. 
kets. Historians such as Hawley ${ }^{28}$ and Galambos ${ }^{29}$ suggest that trade associations were generally ineffective in strengthening markets during the 1920's, even with considerable infornal support for such activity froin the government. ${ }^{30}$ The temptation to cheat appears to have been too great to maintain price agreements purely through voluntary undertakings. ${ }^{31}$ To be sure, price fixing can be sustained if enforced or supported by government action, as is the case with many agricultural products. ${ }^{32}$ But the price support system and related inducements to restrict the output of agrieultural products suggest that it is difficult to design and maintain long-term workable mechanisms for lawful price fixing. Similarly, the oil industry, which has had greater success than others in developing a stable market, has had a history of government intervention and regulation..$^{33}$ If price-fixing schemes are unstable even when the government condones or aids them, they should be nuch less stable when illegal.

\section{The Implications of Homogeneity}

The greater number of price-fixing cases brought in homogeneous markets suggests that collusive behavior is a greater problem in such narkets. However, it cannot be determined whether this problem is due to the greater detectability of collusion in homogeneous product markets or to a greater propensity of firms to collude in such markets. If there is a greater propensity to collude, a structural approach to antitrust enforcement would be preferred because the difficulty of securing agreement increases in proportion with the number of firms. The diff(1968).

28. See Hawley, Secretary Hoover and the Bituminous Coal Problem, 42 BUS. HIST. Rev. 247

29. See Galambos, The Cotton-Textile Institute and the Government, 38 Bus. HIST. REv. 186 (1964).

30. This informal support was evidenced in part by the fact that the government rarely prosecuted trade associations for antitrust violations during this period. See id; Hawley, supra note 28.

31. For example, the heavy electrical equipment imdustry was able to maintain a cartel by setting prices and market shares during secret meetings. At least for contracts awarded by sealcd bids, the cartel could immediately detect cheating because it had preselected the firm to be the low bidder. Nevertheless, this cartel also appears to have broken down repeatedly because firms yielded to the teinptation to cheat. See generally R. Sultan, Pricing IN THE Electrical OliGOPOLY (1974). The Guidelines consider complex products like heavy electrical equipment to be more like homogeneous goods for which all characteristics of the product are specified by the buyer in a bidding process.

32. Agriculture is an atomistic homogeneous product market. It is periodically subject to both natural disasters and economic distress from overproduction. The federal governinent has sought to stabilize farm income through a host of prograuns imcluding price supports, crop insurance, acreage reduction, and exemptions from antitrust laws to permit joint marketing of agricultural products. For a review of federal policies and problems generated by attempting to stabilize the markets, see G. Shepherd, FARM Policy: New Directions (1964).

33. See, e.g., J. BLAIR, THE CONTrol OF OIL (1976). 
culty of identifying the cause of collusive behavior makes it difficult to select the best enforcement mechanism.

Section 7 of the Clayton Act takes a structural approach to competitive problems. Its purpose is to prevent the development of market power in its incipiency. ${ }^{34}$ The intrusiveness of this remcdy, however, suggests that it should be used with restramt. Thus, the prophylactic framework of the Clayton Act should not be used if its objectives could be achieved through a narrower remedy that preserves greater freedom in the market. As the Guidelines indicate, a Sherman Act prosecution for explicit price collusion is an alternative to a section 7 action, ${ }^{35}$ and the Sherman Act would be preferable if it could effectively deter or redress anticompetitive behavior because it need only be apphed to wrongful conduct. ${ }^{36}$

It is unlikely, however, that the Sherman Act can displace the Clayton Act. In many cases, anticompetitive behavior associated with an increase in concentration may not be detectable, ${ }^{37}$ thus putting it beyond the reach of the Sherman Act. If competitors are few enough, it may be possible to devclop a durable price-fixing system without either the explicit agreement or "conscious parallehism" that is required to support a prosecution under the Sherman Act. ${ }^{38}$ Using the Clayton Act to discourage concentration can prevent this problem from developing.

In sum, given both Congress' intent that anticompetitive behavior be stopped im its incipiency ${ }^{39}$ and the propensity for price fixing in homogeneous product markets despite numerous Sherman Act prosecu-

34. See L. Sullivan, supra note $22, \S 201$, at 599.

35. Guidelines $\S \operatorname{III}(\mathrm{A})(1)(\mathrm{a}), 47 \mathrm{Fed}$. Reg. at $28,497,71$ CALIF. L. REv. at 656.

36. When dealing with a homogenous product market that is less concentrated, the Sherman Act may also be preferable to the blanket approach of the Clayton Act for other reasons. If one believes that some homogeneous product markets such as commodity markets are extremely unstable and chronically subject to periods of overcapacity that would result in highly concentrated markets, one might conclude that competition would be better served if the industry were permitted to engage im joint activity during periods of economic distress. This appears to be Justice Brandeis' view in American Column \& Lumber Co. v. United States, 257 U.S. 377, 413, 418-19 (1921) (Brandeis, J., dissenting), and the view of countries which pernit crisis cartels. See, e.g., K. Yamamura, ECONOMIC Policy IN Postwar JAPAN 54-69 (1967); Note, Trustbusting in Japan: Cartels and Government-Business Cooperation, 94 HARV. L. REV. 1054 (1981).

Such flexibility is contrary to the American tendency to treat horizontal agreements as per se violations. However, as Louis Galambos has pointed out, per se treatment of horizontal agreements in markets with low concentration seems anomalous because it creates antitrust bias in favor of merger and greater market concentration. Galambos, Loose Combinations and Their Public Control Over Time, in National Competition Policy: Historians Perspectives on AntiTRUST AND GOVERnMENT-BuSINESS Relationships IN THE UNITEd STATES 144 (1981).

37. There is no way to know whether all collusion is detected. A fully effective, durable price-fixing conspiracy may be cumbersome and obvious, but many less coinplete, more transitory restramts of trade will not be prevented if the Sherinan Act is the prinary method of enforcement.

38. See, e.g., supra note 31 (discussing the heavy electrical equipment industry).

39. S. ReP. No. 1775, 81 st Cong., 2d Sess. 4-5 (1950). 
tions, ${ }^{40}$ the Guidelines' special attention to such markets seems justifiable. On the other hand, the competitive impact of even perfect homogeneity on price-fixing agreements is not as unequivocal as the Guidelines appear to assume. Homogeneity may also undermine price-fixing agreements. Moreover, as the next Part explams, heterogeneity can facihtate collusion and other equally undesirable results.

II

\section{Segmented Product Markets}

As the introductory example illustrates, ${ }^{41}$ the competitive problem posed by segmented markets is analogous to a market division agreement between firms within an industry. Each firm agrees to sell its products to a select group of customers (i.e., one segment of the market) and thus each gains market power in that segment. The problem for antitrust is that such segmentation inay arise from individual firm strategies and the resulting market power may endure without interfirm collusion. The result is a competitive problein that is particularly difficult to remedy.

Because there is no agreement, the Sherman Act may be unable to eliminate the market power, even though the harm is similar to that resulting from exphicit collusion. Consequently, if antitrust is to prevent the increase in market power, a structural approach, such as that provided by the merger provisions of the Clayton Act, inust be used. A structural approach can be used to prevent the market from becoming so concentrated that it can be conveniently divided into noncompeting segments.

At least some segmented markets should be of great antitrust concern because supranormal profits can be earned over extended periods. Because of the inore complex market structure, it is often difficult to identify the factors that account for such stable excess earnings. Product quality, production efficiency, product image, anticompetitive behavior, or some coinbination of these and other factors may produce excess profits in a given market. Whatever factors influence profitability of particular firms, a segmented market can increase industry profits by making coinpetition between firms less volatile, thus facilitating enduring cooperative behavior. ${ }^{42}$ The combination of these elementshigh earnings, difficulty in isolating anticoinpetitive acts, and the durability of cooperative behavior-makes segmented product markets a highly appropriate area to target in section 7 enforcement.

\footnotetext{
40. See F. SCHERER, supra note 21, at 175-77.

41. See supra text accompanying notes 3-7.

42. In contrast, mcreased profitablity in a homogeneous product market can only occur as a result of reduced supply. The creation of such sliortages is often the primary goal of cartelization.
} 
Identifying segmented product markets is difficult. ${ }^{43}$ Unlike homogeneous product markets, segmented product markets do not have precisely defined characteristics. A product market may be segmented by numerous factors such as vertical integration, quality, image, type of customer, or service. In addition, the theory of segmented markets is not as developed as price theory. It is, therefore, difficult to describe and predict the imteraction of firms in segmented product markets. Nevertheless, the concept of segmentation, which is central to much of the strategy taught in business schools, has some general characteristics that are helpful in evaluating the relative risks posed by concentration in hoinogeneous and segmented product markets. It should be remeinbered that busmess strategy is principally a theory of action that has analyzed and developed tactics to imcrease a firm's profits. It is not a theory that considers the social costs or benefits of particular firm action.

\section{A. Business Strategy Theory}

Business strategy theory assumes that executives of busmesses in segmented markets will normally be aware that their decisions affect the inarket. ${ }^{44}$ It also assumes that a busmess can and should increase profits by strategic actions. Finally, it assumes that a firm will generally be inost profitable if it can find and maintain a defensible market seginent.

\section{The Benefits to Firms from Segmentation}

Business strategy theory stresses that each firm should exploit its comparative advantages and thereby capture its own market segment. In automobile production, for example, one firm might specialize im expensive luxury vehicles, another in high quality engineering for speed, another in endurance on rugged terrain, and another in long car life. According to strategic theory, each firm's profitability can be imcreased if each emphasizes its individual specialty. ${ }^{45}$ By differentiating its products, each firm gains a stronger hold on its customers ${ }^{46}$ and becoines less vulnerable to loss of sales to other firms. It can, therefore, risk raising its prices above a competitive level. ${ }^{47}$

The computer industry provides an example of the advantages to

43. My discussion of segmented markets relies principally on Porter's exposition. See M. PORTER, supra note 18.

44. See, e.g., id. at 47. Firms in homogeneous markets, by contrast, are "price takers."

45. Porter argues that differentiation can be a barrier to entry, thus preserving the profits of a firm that cliooses such a business strategy. See id. at 139.

46. However, the firm is also more vulnerable to changes in public taste if it chooses a narrow segment. Id at 44-46.

47. See supra note 45 . 
firms from segmentation. The computer industry is segmented according to product characteristics such as speed, programmability, nneinory capacity, and coinpatibility with other data processing equipinent. Soine firms sell only preprogrammed equipment, wlile others sell software packages, and still others will help customers write their own programs. Each of these features, alone and in combination, segments the market, for the needs of groups of buyers cannot be met by firms that only provide certain configurations of product and service. The market also can be segmented to the advantage of particular sellers in a number of ways. For example, the seller benefits if the buyer can only buy compatible additional components from the seller of its original equipinent, or if the buyer's investinent in traming his einployees discourages him from replacing existing equipinent with that of competitors, or if the seller has learned important information about the buyer's operations that would be costly for other sellers to learn. All of these increase the inarket power of the seller by nnaking the buyer less price sensitive.

\section{Competitive Problems More Likely to Endure in Segmented Markets}

In a market coinpletely segmented along coinpatible lines, the firms inay be able to adopt a number of mutually beneficial strategies. ${ }^{48}$ These strategies may be short of explicit agreement, such as autoinobile advertising that stresses the advantage of individual transportation over mass transportation, or lobbying for highway construction funds. More significantly, the firms may be able to develop market allocations or pricing policies that raise all of their profits.

The nature of these quasi-agreements is likely to be very different from price fixing in a homogeneous product market, thus inaking excess profits more likely to endure in segmented inarkets. First, the price of "the product" asked by different firms in a segmented market often will vary by large amounts without affecting market shares. Nevertheless, the firms in the market recognize that customers will switch to other sellers if faced with a large enough price differential. The firms thus atteinpt to keep their prices within a general range relative to eacli other. "Agreement" on price in such markets may, therefore, be difficult to identify because there may be a large differential between the prices charged by various firms. Tlius, it is unlikely that the Sherman Act could remedy such a problem.

Second, cheating is often less effective in a segmented product

48. See M. Porter, supra note 18, at 88. As used in this Article, segmentation usually assumes that the industry's segments are compatible. 
market. In a truly homogeneous product market, the entire sales of every firm are at risk if any firm offers even a shghtly lower price. In such markets, the customer will be primarily interested in price because the products are identical. This is not true in a segmented market. When the products are differentiated, even a substantial price differential may not attract all the customers in the target segment or segments. For example, Alchian and Allen, in what appears to be an extreme example, suggest that it would be reasonable for consumers to contimue to buy Coke even if other colas sold for $25 \%$ less. $^{49}$

Third, the incentive to cheat is less than in a homogeneous market because a firm must sacrifice fairly certain profits for speculative gam. For example, a price reduction may force the seller to charge the buyers in its own segment the same lower price, if it wishes to avoid ahenating long-term customers. The attempt to capture an additional segment may jeopardize the firm's hold on its own segment im other ways. Lowering price may be incompatible with its customers' view of qualitative aspects of the product. A lower car price, for example, may be interpreted as being at the expense of endurance, comfort, or car hfe. Similarly, including greater speed features may frighten away customers whose greatest concern is safety.

These deterrents to cheating may also facilitate agreement on a single price or an exact price differential in imdustries where such a differential is traditional. ${ }^{50}$ The firm that departs from a rigid price structure by cuttimg prices risks upsetting the entire pricing structure of its industry, and thereby earning lower profits even if it gams market share.

One need not fully accept the stability of the perfectly segmented market to realize that it presents different competitive problems than those in hoinogeneous markets. ${ }^{51}$ To be sure, firms often try to capture markets from one another. The issue for the purpose of the Guidelines is whether segmentation should count as an "Other Factor" when evaluating the possibility of greater concentration im a product market. Greater risk of pricing above the competitive level is presented by quasi-agreements in segmented markets. This is true even though firms in homogeneous product markets have both a greater need and imcen-

49. A. Alchian \& W. Allen, supra note 16, at 362.

50. Cigarettes competing for the same submarket, for example, almost always sell for the same price despite the existence of at least seven submarkets and product differentiation through heavy advertising. See I. Whitten, Brand Performance in the Clgarette Industry and THE ADVANTAGE OF EARLY ENTRY, 1913-73, at 41 (1979) (FTC Staff Report).

51. Poorly segmented markets-i.e., markets im which firms are trying to create segments that have conflicting characteristics-are significantly less stable than homogeneous product markets. See M. PORTER, supra note 18, at 139-41. 
tive to collude..$^{52}$ The competitive danger posed by segmented markets is that they can more easily maintain supracompetitive prices, with or without explicit agreement, in both good and bad economic times.

In addition, theory is of inuch less help in identifying cooperative conduct in segmented markets. Controlling cheatimg in a homogeneous product market may require a large and obvious monitoring network unless the number of firms is particularly small. In a segmented market, however, a successful quasi-agreement may be reached and maintained with a larger number of firms. The incentive to cheat in a segmented market is less than in a homogeneous inarket because the benefits from cheating are reduced. With no incentive to cheat, the industry need not have any exphicit practices to maintain excess profits. An antitrust conduct approach would thus be rendered impotent because there would be no particular conduct to forbid.

\section{B. Experience}

\section{The Analysts' Conclusions on Segmented Markets}

It is difficult to apply the above theoretical discussion to actual markets. Segmentation can take many forins, and not all will enhance profitability. Consequently, many analysts have simply examined homogeneous and heterogeneous product markets to determine which better facilitates collusion. If, mstead, the analysts had focused on firms pursuing segmentation strategy in heterogeneous inarkets, they would have found that market segmentation has aided coordination.

Scherer's work supports this proposition. He noted that "[h]omogeneity of products appeared more conducive to agreeinent than heterogeneity . . . ."53 He rehed principally on two kinds of evidence gleaned from antitrust cases and economic studies. First, most prosecutions of price fixing have involved fairly homogeneous product inarkets where the firms have attempted to facilitate collusion by further standardizmg the product or terins of sale. ${ }^{54}$ Second, the presence of organizational heterogeneity within a product market-mail-order busmesses, wholesalers, and vertically integrated firms-can add pressure toward instability. ${ }^{55}$ Scherer, nevertheless, recognized that seginentation by product differentiation may facilitate coordination and enhance profits. Scherer writes: ${ }^{56}$

When sellers can build strong brand loyalties or when economies of

52. See supra text accompanying notes $16-20$.

53. F. SCHERER, supra note 21 , at 176.

54. Id.

55. Id. at 204-05. This conclusion seems to closely parallel Porter's analysis of markets with conflicting segments. See infra text accompanying notes 58-63.

56. F. SCHERER, supra note 21, at 203. 
scale in product differentiation raise barriers to the entry of new competition, profits may be higher than they would be with homogeneous products. The net effect of these opposing forces depends in a complex way upon the specific character of product differentiation and the degree to which other influences conducive to coordinated pricing operate.

Despite Scherer's conclusion that lomogeneity better facilitates agreement, lie cited three industries with highly differentiated products-cigarettes, automobiles, and ready-to-eat cereals-as leading examples of industries earning high profits over a long period througl price coordmation. ${ }^{57}$

Porter describes in greater detail the same plienomenon from a tactical busmess perspective. He identifies four primary factors that determine whether market segmentation is likely to result in compatible and peaceful relations or combative and rivalrous relations. The first factor is whether firms (strategic groups) are competing for the same kind of custoiner. Porter observed that when firms target different segments of the market, "their imterest in and effect on each other is much less severe." 58 Furthermore, as the markets become more heterogeneous, competition between the firms is lessened and begims to approximate that found between firms in different industries. ${ }^{59}$

Porter's second factor concerns the use of brand identification. He states that if divergent strategies produce distinct and differing brand preferences, rivalry among the firms would tend to be less intense than if the products were seen as substitutes. ${ }^{60}$

The third factor concerns the number of competitors. According to Porter, a large number of firms implies "great diversity and a high probability that one [firm] will trigger an outbreak of warfare by attacking the position of other [firms] througl price cutting or otler tactics." 61

The final factor concerns the diversity of busimess strategies of the competing firms, as well as the external circumstances that affect them. Differences among firms in strategic variables such as brand identification, cost position, and technological leadership, as well as in external circumstances, sucl1 as relationships to parents or governinents, will result in more vigorous competitive skirmishing. ${ }^{62}$

Porter notes that firms in the segmented market have a clioice between cooperative and individualistic busmess strategies. Firms are

57. Id. at $177-81$.

58. See M. PORTER, supra note 18 , at 139.

59. Id.

60. Id

61. Id

62. Id at $139-40$. 
free to pursue their narrow self-interest at the risk of touching off retaliation, or they may pursue cooperative behavior that improves the profitability of the entire industry. ${ }^{63}$ While he suggests that both strategies nay be appropriate, he insists that firms should be careful lest their individual strategies disrupt the framework of the imdustry's competitive consensus: ${ }^{64}$

[S]electing the right competitive nove involves finding one whose outcoine is quickly determined (no protracted or serious battle takes place) and also skewed as inuch possible toward the firm's own interests. That is, the goal for the firm is to avoid destabilizing and costly warfare, which spells poor results for all participants, but yet still outperform other firms.

\section{Case Law and Segmented Markets}

The above suggests that when firms are few enough and the market adequately segmented, tacit agreements may becoine easier, perhaps even natural. Case law also provides support for the proposition that seginentation can facilitate cooperation. American Tobacco Co. $v$. United States, ${ }^{65}$ for example, contains a long list of instances of large firms acting in parallel in the cigarette market that had becoine seginented by, inter alia, brand loyalty. The actions imcluded coordinated purchasing, sales, and pricing over a long period of time including both prosperity and the Great Depression. ${ }^{66}$ The firms even mamtamed a common strategy during a major challenge by discount cigarette manufacturers. ${ }^{67}$ Whether this conduct was the result of explicit agreenent or mutual awareness, the degree of cohesiveness is striking.

Cohesiveness also seens characteristic of a group of cases im which inajor firms in differentiated product markets coordinated their actions to reduce coinpetition, stabilize the product market and enhance their profits. The movie distribution cases-Interstate Circuit, Inc. v. United States, ${ }^{68}$ United States v. Paramount Pictures, ${ }^{69}$ Milgram v. Loew's, Inc. ${ }^{70}$ and Theatre Enterprises v. Paramount Film Distributing Corp. ${ }^{71}$-are prime examples of cooperative behavior designed to stabilize the inarket. In these cases, a variety of parallel practices were challenged, including uniform prices for first run movies, block book-
63. Id. at 88.
64. Id. at 91 .
65. 328 U.S. 781 (1946).
66. Id. at $800-08$.
67. Id. at 806-08.
68. 306 U.S. 208 (1939).
69. 334 U.S. 131 (1948).
70. 192 F.2d 579 (3d Cir. 195l) cert. denied, 343 U.S. 929 (1952).
71. 346 U.S. 537 (1954). 
ing, and uniform refusals to deal with drive-ims for first-run movies. In general, the courts inferred explicit or imphicit agreements between the movie producers to restram trade im violation of the antitrust laws. As Theatre Enterprises demonstrates, however, the Supreme Court beheved that cooperative behavior, even "conscious parallehsm," could exist without agreement. ${ }^{72}$ Such conduct might produce the same anticompetitive effect as explicit agreements, but could not be reached by the Sherman Act.

\section{Implications of Market Segmentation}

The availability of these cooperative strategies to firms in segmented markets poses a major problem for antitrust. Segmentation is a inechanism to enhance industry profits that lias not generally been held in violation of the antitrust laws. For exainple, in Theatre Enterprises, the Supreme Court discussed the type of cooperative business behavior advocated by Porter, and declared that it had "never held that proof of parallel business behavior conclusively established [unlawful] agreeinent . ..."73 Thus, once established, an effectively segmented (and anticompetitive) inarket structure may be immune froin antitrust attack.

Because it is difficult to secure an effective remedy in a segmented market, even a successful prosecution under the Sherman Act does not necessarily solve the competitive problem. For example, in American Tobacco, ${ }^{74}$ a leading conscious parallelism case, the government never secured a remedy to prevent further violations by the cigarette industry. ${ }^{75}$ The "crime" committed by the cigarette industry "essentially consisted of a few firms taking one another's presence into account. They could hardly stop doing this unless their number were increased considerably." At At the same time, however, the case "did not establish that domination of the market by three firms constitutes a monopoly and warrants breaking up the firms." 77 The difficulty faced by the gov-

72. Conscious parallelism alone will not satisfy the Sherman Act's conspiracy requirement. Id. at 541 .

73. Id.

74. American Tobacco Co. v. United States, 328 U.S. 781 (1946). In American Tobacco, the three largest cigarette producers, who then controlled about five-sixths of the United States cigarette market, were convicted of violating the [Sherman Act]. The evidence did not show that they had conspired to intimidate their rivals, or even that they had overtly conspired at all. Instead, it showed that the three had acted in closely parallel fashion as if they were taking full account of their influence on one another and on the market. In short, the concept of "monopolization" was extended to cover an industry with high concentration and tacit, rather than open, collusion.

R. CAVES, AMERICAN INDUSTRY 90 (4th ed. 1977) (emphasis in original).

75. R. CAVEs, supra note 74 , at 91.

76. Id

77. Id. (emphasis in original). 
ernment in its attempts to obtam a remedy provides "an important inoral for any who propose extended use of the Sherman Act against sucli 'close-knit' oligopolies." 78

Because of the difficulty in shaping a remedy when an anticornpetitive structure appears in a segmented market, the Clayton Act slould be used to prevent sucli market structures from developing. Accordingly, mergers should be forbidden in product markets that are being segmented in cooperative patterns. Prohibiting such mergers is a basic purpose of the Celler-Kefauver amendments to the Clayton Act, which were designed to prevent monopolistic tendencies in tleir incipiency. ${ }^{79}$ Moreover, both Porter and Caves found that, as is true in homogeneous markets, a greater number of firms in a segmented market makes intramdustry cooperation more difficult. ${ }^{80}$

Because both segmented markets and hoinogeneous markets should be the subject of antitrust concern, it need not be determined with certainty whether the competitive problems posed by segmented inarkets should be of more or less concern than those posed by hoinogeneous markets. Examination of the factual issues involved, ${ }^{81}$ however, suggests that the importance of segmented markets has been unneccessarily discounted.

First, even without knowing about the relative prevalence of collusion in homogeneous markets, it is important to note that such collusion generally requires conduct prohibited by the Sherman Act. In many instances, particularly where the market contains a large number of firms, successful collusion requires a fairly elaborate monitoring structure. A conduct reniedy can eliminate such an agreement because the monitoring structure can be dismantled relatively easily. In contrast, the complexities of a segmented market often make direct monitoring inpossible and require that any agreement be based primcipally on nutual awareness. This is almost impossible to eliminate with a conduct remedy. Thus, in segmented product markets cooperation is most likely to be prevented, if at all, by a structural approacli such as prohibiting mergers.

Second, tacit agreement is more likely in a segmented product market than in a homogeneous product market. For a homogeneous product market to support a tacit agreement, the number of firms

78. Id.

79. S. Rep. No. 1775, 81 st Cong., 2d Sess. 4-5 (1950).

80. M. PorTer, supra note 18 , at 139.

81. These factual issues include: How prevalent is sustained cooperative behavior in segmented markets compared with sustained collusion in hoinogeneous inarkets? Is such cooperative behavior sustainable with a greater number of firms than collusion? Are sustainable profit margins likely to be greater as a result of cooperative behavior or collusion? 
would probably have to be very small. In contrast, tacit agreement is possible in a segmented market with a greater number of firms.

Third, greater problems with segmentation can be expected as the recommendations of business analysts like Porter become mcreasingly persuasive to executives. There is good reason to believe that well-segmented markets, such as cigarettes or cereals, can sustain high profits over longer periods, while truly homogeneous markets, such as coal and cotton, cannot do so, because restrictimg output is the only way to achieve higher prices in such markets. It is less clear that segmentation can provide higher profits than can conspiracies in semi-homogeneous markets, such as heavy electrical equipment. Because segmentation by itself is lawful, however, we can expect executives increasingly to attempt to segment their markets, with foreseeable anticompetitive consequences.

While evidence of the prevalence of collusion remains critical, I think the Guidelines would do well to be more concerned with the danger of intra-industry cooperation im segmented markets ${ }^{82}$ and less concerned with collusion im homogeneous product markets, which can be redressed by conduct remedies. Cooperation through mutual awareness to the disadvantage of the consuming public is a problem that has generally proved intractable to antitrust. Such a problem is more likely to occur in segmented product markcts. It is difficult to forinulate remedies to prevent firms from indcpendently actimg in their best interest. The best approach is to prevent a product market from becoming so concentrated that mutually beneficial anticompetitive actions become obvious to all mdustry members. The merger prohibitions of the Clayton Act seem well suited to accoinplish this task. Unfortunately, the Guidelines do not reflect this concern.

\section{CONCLUSION}

Both product homogeneity and market segmentation can facilitate the development of market power. Thus, both ought to be included as "Other Factors" that may mdicate when concentration indices understate market power. For different reasons, both can facilitate explicit price agreements or their equivalent-homogeneity because it reduces the terms that must be agreed to and monitored, and segmentation because it reduces the mcentive to cheat. The competitive effects of each, howevcr, depend on the number of competitors, the type and degree of product differentiation and other factors. These are not different points

82. The Guidelines refer to some factors present in cooperatively segmented markets-e.g., stable market shares and persistent high profits. These, however, are consequences of segmentation, not predictors thereof. See Guidelines $\S \mathrm{III}(\mathrm{C})(4), 47$ Fed. Reg. at 28,499, 71 CALIF. L. Rev. at $659-66$. 
on a single coinpetitive spectrum. They are different structural components that can be critical to the formation of dissimilar anticompetitive configurations based on different sets of common interests between competitors. Accordingly, the Guidelines ought to note that the relevance of product homogeneity and market segmentation must be determined in each case.

Segmented narkets deserve special attention in the Guidelines because their anticompetitive potential is not generally redressable elsewhere in antitrust law. It is difficult to determine how the Guidelines should deal with segmented markets. To reflect fully their potential for anticompetitive cooperation requires more analysis than existing research permits. It requires further delineation of characteristics of cooperative and conflicting patterns of market segmentation. For the present, however, we can say that market segmentation matters and should therefore be a significant factor to be considered in determining the likely anticonpetitive impact of a nerger. 